\title{
Activity budgets and foraging behavior of bison on seeded pastures
}

\author{
BRUCE D. RUTLEY AND ROBERT J. HUDSON
}

Authors are director, Boreal $R \& D$, Fairview, AB TOH 1LO; and professor, Wildife Ecology and Management, University of Alberta, Edmonton, Canada T6G 2H1. At the time of the research, the first author was director of Research and Educational Services, Center for Agricultural Diversification, Northern Lights College, Dawson Creek, B.C. V1G 4 G2.

\begin{abstract}
Activity budgets and foraging behavior of yearling bison (Bison bison $\mathrm{L}$.) on pasture were studied during quarterly trials between June 1994 and December 1995. Daily activity patterns were polyphasic with alternating bouts of foraging and resting activity. During winter, bison displayed 2 main daytime foraging bouts and significant nighttime foraging. During summer, phasic activity was poorly expressed due to the increased number of cycles. Total foraging time declined from summer to winter $(763$ \pm 62 to $470 \pm 32$ min day $^{-1}$ ) while bedding bout length increased $\left(121 \pm 13\right.$ to $\left.276 \pm 26 \mathrm{~min} \mathrm{day}^{-1}\right)$. Bison selected forage higher in crude protein $(12.9 \pm 0.8$ vs $10.0 \pm 0.8 \%)$, higher in predicted digestible energy $\left(2.70 \pm 0.09\right.$ vs $2.17 \pm 0.09$ Mcal kg $\left.{ }^{-1}\right)$, lower in acid detergent fiber $(31.9 \pm 0.9$ vs $38.8 \pm 0.9 \%)$, and lower in lignin $(4.8 \pm 0.3$ vs $6.8 \pm 0.3 \%$, respectively) than forage available within grazed patches.
\end{abstract}

Key Words: nutritional ecology, forage intake, annual grazing, forage selection

Ruminants exhibit regular polyphasic activity patterns, alternating between foraging and resting/ruminating activity (Gates and Hudson 1983, Hudson and Watkins 1986). This basic pattern is pre-empted by walking between bedding and feeding sites, moving to alternate feeding sites, social interactions, and predator avoidance (Renecker and Hudson 1993). Wild ruminants alter their daily activity pattern in response to seasonal fluctuations in forage biomass and environmental temperature (Trudel and White 1981, Hudson and Frank 1987).

Foraging behavior of bison (Bison bison L.) (Peden et al. 1974, Hudson and Frank 1987, Plumb and Dodd 1993) and partial activity budgets (Belovsky and Slade 1986) have been described. However, there is little published information on foraging behavior and activity budgets of farmed bison annual grazing seeded pasture. Under these conditions, full expression of activity rhythms and the rumen repletion-depletion cycle is expected. This study was conducted to provide this information and to determine the response of bison to seasonal variations in forage

Research was funded primarily by Alberta Agriculture Research Institute. Dr. P. Blenis assisted with statistical analyses. Authors wish to thank Norwest Labs for composition analyses. The assistance of the anonymous reviewers was appreciated.

Manuscript accepted 21 Jul. 2000

\section{Resumen}

El patrón de actividades y el comportamiento de forrajeo de bisontes (Bison bison L.) apacentando praderas se estudiaron en ensayos cuatrimestrales conducidos entre junio de 1994 y diciembre de 1995 . Los patrones de actividad diaria fueron polifásicos con ratos alternantes de actividades de descanso y apacentamiento. Durante el invierno, los bisontes mostraron 2 ratos principales de apacentamiento diurno y apcentamiento nocturno significativo. En verano, la actividad fasica fue pobremente expresada debido al incremento del número de ciclos. El tiempo total de forrajeo disminuyó del verano al invierno (de $763 \pm 62$ a $470 \pm 32$ min día-1) mientras que la longitud de los períodos de descanso aumentó (de $121 \pm 13$ a $276 \pm 26$ min día- $\left.{ }^{-1}\right)$. El forraje selecionado por el bisonte, comparado con el disponible dentro de los parches apacentados por ellos, fue más alto en proteína cruda $(12.9 \pm 0.8$ vs $10.0 \pm 0.8 \%)$ y energía digestible predicha $(2.70 \pm$ 0.09 vs $\left.2.17 \pm 0.09 \mathrm{Mcal}^{\mathrm{kg}} \mathrm{g}^{-1}\right)$ y más bajo en fibra ácido detergente $(31.9 \pm 0.9$ vs $38.8 \pm 0.9 \%)$ y lignina $(4.8 \pm 0.3$ vs $6.8 \pm$ 0.3\%).

quality. We document the response specific to changes in activity budgets (foraging, resting and minor activity time), and length of foraging and resting bouts. We also tested the hypothesis that bison would select forage of a higher quality than that available to them from within grazed patches or the sward.

\section{Materials and Methods}

\section{Location and Climate}

The study was conducted at the Center for Agricultural Diversification, Dawson Creek, British Columbia (55 44' 30" N, $120^{\circ} 30^{\prime} 00^{\prime \prime} \mathrm{W}$; elevation $670 \mathrm{~m}$ ) located $600 \mathrm{~km}$ northwest of Edmonton, Alberta. The area is located entirely within the Alberta Plateau - an extension of the Great Plains. The area is in the aspen grove (wooded bluffs interspersed with open grasslands) and mixed-wood trembling aspen (Populus tremuloides L.), balsam poplar (Populus balsamifera L.), white spruce (Picea glauca L.), black spruce (Picea miriana L.), and willow (Salix spp. L.) sections of the boreal forest (Department of Energy, Mines and Resources 1974). Annual average rainfall is $430 \mathrm{~mm}$ with $330 \mathrm{~mm}$ falling during the growing season (April to September). Annual snow accumulations of $40 \mathrm{~cm}$ are common but are reduced due to recurring chinook winds. Mean January, 
July, and annual temperatures at Dawson Creek, British Columbia are $-15,15$, and $1 \mathrm{C}$, respectively, whereas daily temperatures of 32 (August) and -44 C (January) are extremes.

\section{Vegetation and Phenology}

The study pasture was 5.4 ha in size, was fenced for bison, and had a southern aspect. It was established over 10 years earlier to introduced grasses and forbs, had not been fertilized for 5 years, yet remained productive. Grasses predominated and included smooth brome (Bromus inermis Leyss.), timothy (Phleum pratense L.), quackgrass (Elytrigia repens (L.) Nerski), and Kentucky bluegrass (Poa pratensis L.). Predominant cultivated forbs were alfalfa (Medicago sativa L.) and red clover (Trifolium pratense L.). Dandelion (Taraxacum officinale Weber.) was the predominate weedy forb. Although, forages began growth in late April, they were unable to sustain grazing until late May. Dandelions emerged in mid-May and were the most visible dicot in early June. Inflorescence of grasses appeared by mid-June and alfalfa was in full bloom by 1 July. First frost occurred in mid-September and grasses senesced by late September.

\section{Study Animals}

Three male and 3 female bison yearlings were selected from a local commercial herd and transported to the study location in late May each year. Animals were selected from the 1993 calf crop for Year 1 trials (June 1994 to March 1995) and from the 1994 calf crop for Year 2 (June 1995 to December 1995). Selected bison $(228 \pm 17 \mathrm{~kg}$ Year 1; $213 \pm 15 \mathrm{~kg}$ Year 2) were representative of commercial bison (209 \pm 1 kg; Rutley et al. 1997). Colored ear tags were attached in both ears prior to release into study pasture. Study animals were used in conjunction with another experiment (Rutley and Hudson 2000).

\section{Activity Budgets}

Bison were observed for activity during 7 trial periods conducted at each equinox and solstice between June 1994 and December 1995. The 7 trial periods included June 1994, September 1994, December 1994, March 1995, June 1995, September 1995, and December 1995. Two consecutive 24-hour observation sessions began 6 days (Day-6) prior to the handling of the study animals (designated as Day 0). Three days after the study animals were handled, and in conjunction with the collection of fecal samples, a subsequent 24-hour observation session occurred (Day 3). Disturbance attributed to the presence of the observers was considered minimal. Full moon corresponded with at least a portion of the first 5 trial periods.

Animals were observed from a truck with binoculars. Activities of individual animals were recorded at 5-minute intervals using the instantaneous scan method (Altmann 1974). Activity categories were: 1) foraging-actively engaged, 2) foraging moderately engaged, 3) foraging-consuming hay, 4) ruminating, 5) resting-standing, 6) resting-lying (bedding), 7) restingsleep (laying flat out), 8) minor-water, 9) minor-walking, 10) minor-play, after Gates and Hudson (1983). Bison did not have access to browse. Interacting with other bison, grooming and 'milling' were included in the minor activity category. Location within the field by grid and weather were simultaneously recorded.

The analysis was based on 38,880 individual records, recorded at 5-minute intervals, obtained during 6,048 scans within twenty-one, 24-hour observation sessions. Because it was not always possible to identify individuals during night hours, only the number of animals participating in an activity were recorded and used for analyses. To accommodate occasional unequal group sizes and different starting times, the following method of summing was used. The total number of animals observed and the number of animals participating in a designated activity during each 5-minute interval was recorded. The number of animals participating in each category for each 5-minute interval over the next 24 hours was summed to become the category 24-hour total (CT24). The CT24 for each category was then expressed as a ratio of the total number of possible animal observations (CT24\%). The CT24\% data from the two, 24-hour observation sessions at Day -6, combined with the Day 3 observation session CT24\% data, became the data set for the trial period. For the final analyses of activity budgets, the subcategories within foraging, resting and minor activity were collapsed (Gates and Hudson 1983).

Length of foraging bout was calculated as the interval between the time when the majority (> 50\%) of the group began foraging until the majority stopped foraging. Bedding bouts were defined as the interval between when the majority of the herd was laying down until the majority was standing up and moving away from the bedding site. Time foraging or bedded was calculated as the sum of 5-minute intervals associated with that activity.

\section{Forage Biomass and Quality}

To estimate available forage within the study pasture (sward), ten, $0.5-\mathrm{m}^{2}$ quadrats were assigned in a completely random design in Year 1 and a stratified random design in Year 2. In Year 2, the study pasture was divided, by grid, into 10 equal areas. A location within the grid was selected at random and the corresponding site within the field was staked (station). In conjunction with each trial period, a site immediately adjacent to the station was sampled in a manner that prevented resampling.

Bison were tracked during each trial period to determine if they grazed areas within the sward that were different from the sward in general. Once defoliation was confirmed, bison were gently disturbed and the grazed area flagged (grazed patch). Ten sites were identified during each trial period. Within each grazed patch, the site of defoliation was identified. Adjacent forage that was similar to the defoliation site, yet had escaped immediate grazing, was sampled (feeding station). The composition of consumed forage was determined from 20 emulated bites collected from each feeding station (Hudson and Frank 1987).

Plant height for both the sward and grazed patches was estimated as the average of 12 measures of plant height, selected at random within a $1 / 12$ area by grid within the $0.5-\mathrm{m}^{2}$ quadrat. An ocular estimate, taken from $1.2 \mathrm{~m}$ above the quadrat, was used to estimate the percentage of bare ground:grasses:weedy forbs:cultivated forbs:litter:feces for each sward site and grazed patch. Both sward sites and grazed patches were harvested with hand shears and hand raked to simulate close grazing. Harvested forage was separated as grasses, forbs and litter, dried at $60 \mathrm{C}$, and stored until forwarded for composition analyses for crude protein (CP), calcium $(\mathrm{Ca})$, phosphorus $(\mathrm{P})$, potassium $(\mathrm{K})$, magnesium $(\mathrm{Mg})$, sodium $(\mathrm{Na})$, acid detergent fibre (ADF), digestible energy (DE), and acid detergent lignin (ADL) (Norwest Labs, Lethbridge, AB).

Growing conditions for 1994 and 1995 were typical for the Peace Country. Because the stocking rate within the trial pasture was so low, following the June 1994 trial the study animals were removed to an adjacent pasture and 22, two-yearold bison bulls were grazed for 12 days to emulate moderately intense grazing. Trial bison were not returned until 21 days 
before trial 2 (September 1995). In Year 2, no additional grazing occurred and the study animals remained within the pasture for the duration of the year. During the growing season, forage biomass within the sward ranged from $288 \mathrm{~g} \mathrm{~m}^{-2}$ to $196 \mathrm{~g} \mathrm{~m}^{-2}$ (Table 1).

Table 1. Biomass within sward sites and grazed patches.

\begin{tabular}{lcc}
\hline \hline Trial Period & Sward site & Grazed patch \\
\hline & $\left(\mathrm{g} \mathrm{m}^{-2}\right)$ & $\left(\mathrm{g} \mathrm{m}^{-2}\right)$ \\
Jun. 1994 & 275 & 263 \\
Sept. 1994 & 288 & 311 \\
Dec. 1994 & 253 & na \\
Mar. 1995 & 8 & 16 \\
Jun. 1995 & 281 & 297 \\
Sept. 1995 & 196 & 231 \\
\hline
\end{tabular}

${ }^{7}$ Only forage above the snowpack was considered available.

In March 1995 and December 1995 bison did not graze due to severe icing of pasture and heavy snow cover, respectively. As they did not venture far from the plowed roadway required for vehicle access, and in the interests of their welfare, supplemental hay was provided (supplementation; March 1995, 9.9\% CP mixed grass/legume hay; December 1995, 8.3\% CP oat hay). In March 1995, after a series of snow, chinook and re-freezing cycles, available forage was restricted to $8 \mathrm{~g} \mathrm{~m}^{-2}$ within the sward. When bison attempted to graze in March 1995, they sought out sites where forage was above the snowline. However, only a very limited amount of forage was available $\left(16 \mathrm{~g} \mathrm{~m}^{-2}\right)$.

\section{Statistical Analyses}

Gender was not evaluated as a source of variation. A one-way analysis of variance (ANOVA, MS Excel ver 5.0) tested seasonal differences in foraging, resting and minor activity, and plant height for each trial period.

Seasonal differences in the activity budget, foraging and bedding bouts, foraging and bedding bout length, and total foraging and bedding time were determined using the PROC MIXED procedure (SAS 1996). Three season-feed groups were created. The summer grazing group consisted of the June 1994, September 1994, June 1995 and September 1995 trials. The December 1994 trial was the winter grazing group. The March 1995 and December 1995 trial periods were included in the supplementation group. Season-feed group was included in the model as a fixed effect. Trial within season-feed group (error term) was included as a ran-

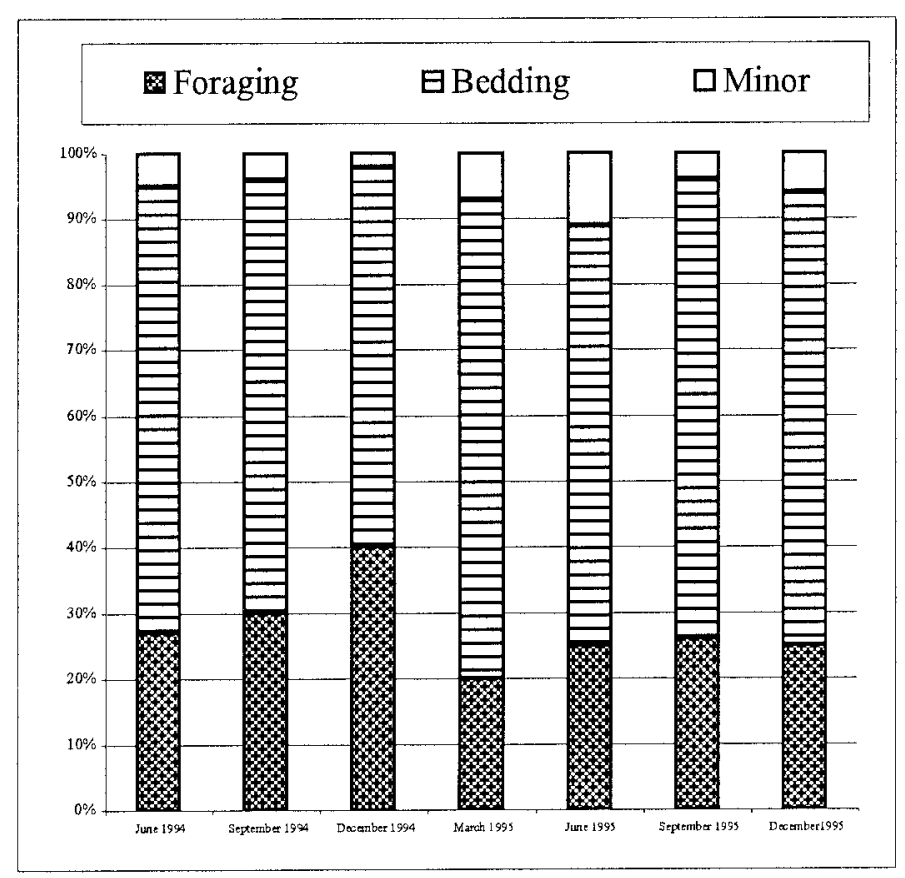

Fig. 1. Percentages of the 24 hour activity budget for yearling bison during indicated trial period.

dom effect. Tukey's test was used for multiple comparisons.

As the dependent variables associated with quadrat structure and forage composition were correlated with each other, analyses were conducted using GLMMANOVA (SAS 1996). Univariate ANOVA was reported for individual dependant variables. Due to the limited number of independent observations, multivariate analyses were performed on only crude protein and acid detergent fiber in the PROC GLM-MANOVA procedure (SAS 1996).

Mean composition of seasonal forage within feeding stations, grazed patches and sward sites were determined using the PROC MEANS procedure (SAS 1996). Due to the limited number of independent observations, multivariate analyses were performed including only crude protein and acid detergent fiber in the PROC

GLM-MANOVA procedure (SAS 1996). This procedure was repeated including crude protein and acid detergent lignin in the model.

All differences discussed in the Results and Discussion were statistically significant at the $5 \%$ level of probability.

\section{Results}

\section{Seasonal Activity Budgets}

Resting and foraging were the most time consuming activities of yearling bison (Fig. 1). Time foraging was always less than time resting and ranged from $40 \pm$ $2 \%$ while grazing in December 1994 to 20 $\pm 2 \%$ during supplementation in March 1995. Bison allocated more time to foraging during winter grazing $(39.6 \%)$ than for summer grazing $(26.6 \%)$ or during supplementation $(22.0 \%)$ (Table 2). Time resting

Table 2. Percentages ( \pm SE) of the 24 hour activity budget for yearling bison by season-feed group ${ }^{1}$.

\begin{tabular}{|c|c|c|c|}
\hline \multirow[b]{2}{*}{ Season-feed group } & \multicolumn{3}{|c|}{ Activity } \\
\hline & Foraging & Resting & Minor \\
\hline & $\ldots \ldots$ & $----(\%)---$ & $-\ldots-\ldots$ \\
\hline Summer grazing $^{2}$ & $26.6^{\mathrm{b}} \pm 1.2$ & $67.2^{\mathrm{ab}} \pm 1.3$ & $6.2^{\mathrm{a}} \pm 1.5$ \\
\hline Winter grazing $^{3}$ & $39.6^{\mathrm{a}} \pm 2.4$ & $58.5^{\mathrm{b}} \pm 2.6$ & $1.8^{\mathrm{a}} \pm 3.1$ \\
\hline Supplementation $^{4}$ & $22.0^{\mathrm{b}} \pm 1.7$ & $71.1^{\mathrm{a}} \pm 1.9$ & $6.9^{\mathrm{a}} \pm 2.2$ \\
\hline
\end{tabular}

${ }^{\mathrm{T}}$ Means $( \pm \mathrm{SE})$ within columns with different letters are significantly different at $\mathrm{P}<0.05$.

${ }^{2}$ Summer grazing = Jun. 1994, Sept. 1994, Jun. 1995, and Sept. 1995 grazing periods

${ }^{3}$ Winter grazing = Dec. 1994 grazing period.

${ }^{4}$ Supplementation = Mar. 1995 and Dec. 1995 grazing periods. 
Table 3. Foraging and bedding activities of yearling bison summarized by season-feed group ${ }^{1}$.

\begin{tabular}{|c|c|c|c|c|c|c|}
\hline \multirow[b]{2}{*}{ Season-feed group } & \multicolumn{3}{|c|}{ Foraging } & \multicolumn{3}{|c|}{ Bedding } \\
\hline & $\begin{array}{l}\text { Number of } \\
\text { foraging bouts }\end{array}$ & $\begin{array}{l}\text { Foraging } \\
\text { bout length }\end{array}$ & $\begin{array}{c}\text { Total foraging } \\
\text { time }\end{array}$ & $\begin{array}{c}\text { Number of } \\
\text { bedding bouts }\end{array}$ & $\begin{array}{l}\text { Bedding } \\
\text { bout length }\end{array}$ & $\begin{array}{c}\text { Total bedding } \\
\text { time }\end{array}$ \\
\hline & (bouts day $^{-1}$ ) & (minutes) & (min. day ${ }^{-1}$ & (bouts day $^{-1}$ ) & (minutes) & $\left(\min\right.$ day $\left.^{-1}\right)$ \\
\hline Summer grazing $^{2}$ & $8.0^{\mathrm{a}} \pm 1.0$ & $69^{a} \pm 9$ & $470^{b} \pm 32$ & $6.6^{\mathrm{a}} \pm 0.5$ & $121^{b} \pm 13$ & $793^{a} \pm 31$ \\
\hline Winter grazing $^{3}$ & $6.7^{\mathrm{a}} \pm 2.0$ & $123^{\mathrm{a}} \pm 17$ & $763^{\mathrm{a}} \pm 62$ & $3.0^{\mathrm{a}} \pm 1.0$ & $276^{\mathrm{a}} \pm 26$ & $698^{\mathrm{a}} \pm 61$ \\
\hline Supplementation $^{4}$ & $5.5^{\mathrm{a}} \pm 1.4$ & $77^{\mathrm{a}} \pm 12$ & $418^{\mathrm{b}} \pm 44$ & $5.8^{\mathrm{a}} \pm 0.8$ & $142^{b} \pm 18$ & $795^{\mathrm{a}} \pm 43$ \\
\hline
\end{tabular}

Means ( \pm SE) within columns with different letters are significantly different at $\mathrm{P}<0.05$.

${ }_{3}^{2}$ Summer grazing = Jun. 1994, Sept. 1994, Jun. 1995, and Sept. 1995

${ }^{3}$ Winter Grazing = Dec. 1994.

${ }^{4}$ Supplementation = Mar. 1995 and Dec. 1995.

during winter grazing $(58.5 \%)$ was shorter than during supplementation $(71.1 \%)$. Time resting during summer grazing was not different from time resting during supplementation. Minor activities ranged from $2 \pm 1 \%$ of the activity budget during
December 1994 to $12 \pm 1 \%$ during June 1995 (Fig. 1), however seasonal differences were not significant (Table 2).

During winter grazing, bison foraged 763 min day $^{-1}$ compared with 470 and 418 min day $^{-1}$ during summer grazing and supplementation, respectively (Table 3 ).

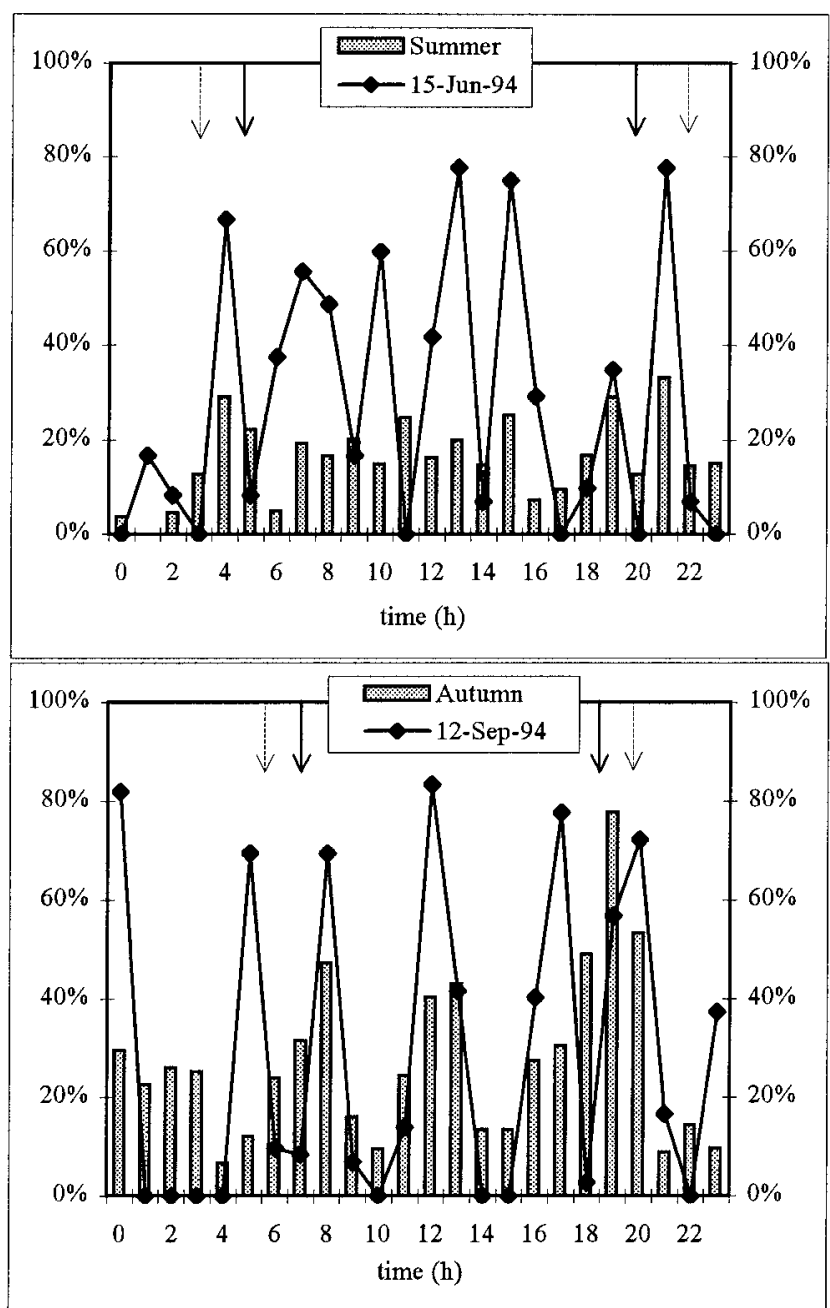

Fig. 2. Averaged seasonal daily foraging patterns (solid bars) and the foraging pattern for a single day (line) expressed as a percentage of time bison were active within each 1-hour interval. Top: summer grazing. Bottom: autumn grazing. Sunrise-sunset indicated by solid arrow. Daylight-dark indicated by broken arrow.
Bedding bouts were longest during winter grazing (276 min day ${ }^{-1}$ ) compared with 121

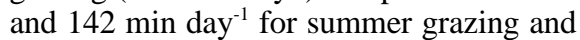
supplementation, respectively (Table 3 ).

\section{Daily Activity}

Bison alternated foraging and resting bouts over the 24-hour activity cycle. Phasic activity was poorly expressed in the June grazing period due to the increased number of cycles (Fig. 2). In June, bison tended to bed immediately following a foraging bout with rumination occurring half the time. Bedding was soon followed with another foraging period. Near sundown bison tended to become quite active and milled for some time prior to an intense foraging bout as darkness fell.

During September grazing, a prolonged foraging bout began prior to sunrise (Fig. 2). A mid-morning rest, mid-day foraging period, and late afternoon rest followed, with foraging activity increasing in frequency in late afternoon, peaking between sundown and dusk. Following dusk, bison tended to bed for a few hours, then graze during the early morning hours before bedding until near dawn.

Winter grazing patterns were similar to September patterns except that there were only 2 main grazing bouts during the day, following sunrise and prior to sunset (Fig. 3). Midnight grazing activity occurred regularly and rivaled early morning grazing. Minor activities were minimal during this period.

Severe snow conditions limited grazing in March 1995 and December 1995. An extended bedding period prior to sunrise, more limited nighttime foraging, and less defined foraging-resting cycles during the day (supplementation, Fig. 3), resulted. Activity declined sharply following sundown.

In comparison to winter grazing (December 1994), supplemented bison (December 1995) exhibited a foragingfeeding pattern with 1) less pronounced foraging peaks following sunrise and near 
Table 4. Quadrat composition within grazed patches and sward sites-June and September trial periods data pooled ${ }^{1}$.

\begin{tabular}{|c|c|c|c|c|c|c|c|}
\hline \multirow[b]{2}{*}{ Type } & \multicolumn{6}{|c|}{ Quadrat Composition } & \multirow[b]{2}{*}{ Feces } \\
\hline & $\begin{array}{l}\text { Plant } \\
\text { height }\end{array}$ & $\begin{array}{c}\text { Bare } \\
\text { ground }\end{array}$ & Graminoids & $\begin{array}{l}\text { Weedy } \\
\text { forbs }\end{array}$ & $\begin{array}{l}\text { Cultivated } \\
\text { forbs }\end{array}$ & Litter & \\
\hline & $(\mathrm{cm})$ & $(\%)$ & $(\%)$ & $(\%)$ & $(\%)$ & $(\%)$ & $(\%)$ \\
\hline Grazed patches & $24.7^{\mathrm{a}} \pm 1.9$ & $3.8^{\mathrm{a}} \pm 2.2$ & $49.8^{\mathrm{a}} \pm 4.2$ & $14.6^{\mathrm{a}} \pm 2.4$ & $23.4^{\mathrm{a}} \pm 3.4$ & $7.6^{\mathrm{b}} \pm 1.3$ & $0.8^{\mathrm{a}} \pm 0.4$ \\
\hline Sward sites & $26.1^{\mathrm{a}} \pm 1.7$ & $5.9^{\mathrm{a}} \pm 2.2$ & $47.0^{\mathrm{a}} \pm 3.3$ & $13.6^{\mathrm{a}} \pm 2.3$ & $18.5^{\mathrm{a}} \pm 3.0$ & $14.5^{\mathrm{a}} \pm 2.5$ & $0.5^{\mathrm{a}} \pm 0.3$ \\
\hline
\end{tabular}

Plant height was analyzed as a one-way ANOVA quadrat composition was analyzed using the GLM-Multivariate procedure. Means ( \pm SE) within columns with different letters are significnatly different at $\mathrm{P}<0.05$.

sunset, 2) more pronounced resting activity following sundown, and 3) more frequent nighttime foraging cycles during supplementation (Fig. 4).

\section{Sward Structure, Forage Quality and Diet Selection}

There was no difference in plant height,

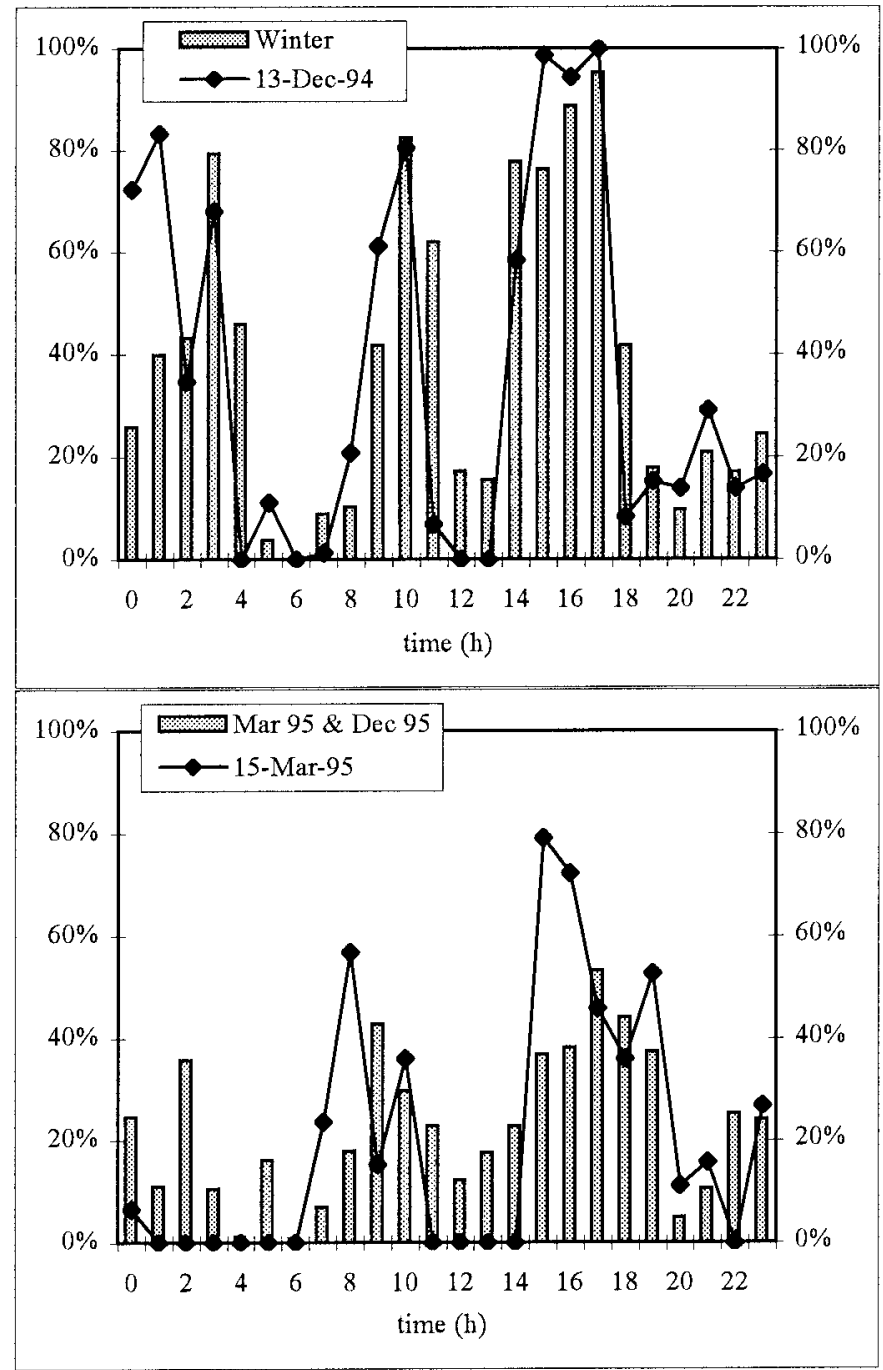

Fig. 3. Averaged seasonal daily foraging patterns (solid bars) and the foraging pattern of a single day (line) expressed as a percentage of time bison were active within each 1-hour interval. Top: winter grazing. Bottom: supplemented. Winter sunrise 0930 sunset 1550. Winter daylight 0820 dark 1700. between grazed patches and sward sites, however, bison selected and grazed patches that were of equivalent plant height but were lower in litter (7.6 vs $14.5 \%$ ) (Table 4).

Chemical composition of forage within feeding stations (emulated bites) was higher in CP (12.9 vs $10.0 \%)$, and predicted DE (2.70 vs $\left.2.17 \mathrm{Mcal} \mathrm{kg}^{-1}\right)$, but lower in

ADF (31.9 vs $38.8 \%)$ and ADL (4.8 vs $6.8 \%)$ than forage within grazed patches (Table 5). Sward sites contained $8.7 \% \mathrm{CP}$, $2.21 \mathrm{Mcal} \mathrm{kg}^{-1}$ DE, 39.0\% ADF, and $6.1 \%$ ADL. Bison consistently grazed both graminoids and forbs within the same feeding station, however, they would frequently graze exclusively on forbs (primarily Medicago spp.) or graminoids.

Chemical composition of consumed forage varied with grazing period. Crude protein was lower in March $(6.6 \pm 4.4 \%)$ than in June $(15.9 \pm 3.1 \%)$ or September $(11 \pm$ $3.1 \%)$. Acid detergent fiber was lower in June $(27.2 \pm 2.9 \%)$ and September $(29.8 \pm$ $2.9 \%)$ than March $(44.7 \pm 4.0 \%)$. Acid detergent lignin was lower in June (3.5 \pm $0.2 \%)$ and September $(4.4 \pm 0.2 \%)$ than March $(8.3 \pm 0.3 \%)$.

Yearling bison obtained all their forage while grazing during December 1994 when snow depth was between 39 and 23 $\mathrm{cm}$ (Table 6). By the beginning of the March 1995 trial, a series of chinooks and refreezing created an impenetrable $28 \pm 4$ $\mathrm{cm}$ snow pack. Therefore, bison consumed supplemented hay. After a chinook, 21 March, 1995, significantly reduced the snow pack to $17 \mathrm{~cm}$, bison resumed grazing on a limited basis. They grazed patches that had significantly less snow cover than the sward and they grazed patches that contained significantly greater accessible forage biomass than was contained within sward sites.

\section{Discussion}

Bison adjusted grazing behavior in relation to their seasonal nutritional requirements and pasture conditions. This was evident both in activity budgets and selectivity in foraging.

\section{Activity Patterns}

Activity patterns for free-grazing bison were distinctly polyphasic in most seasons, a pattern common among wild and domestic ruminants (Eriksson et al. 1981). Activity patterns were generally consistent day to day, however they would shift an 


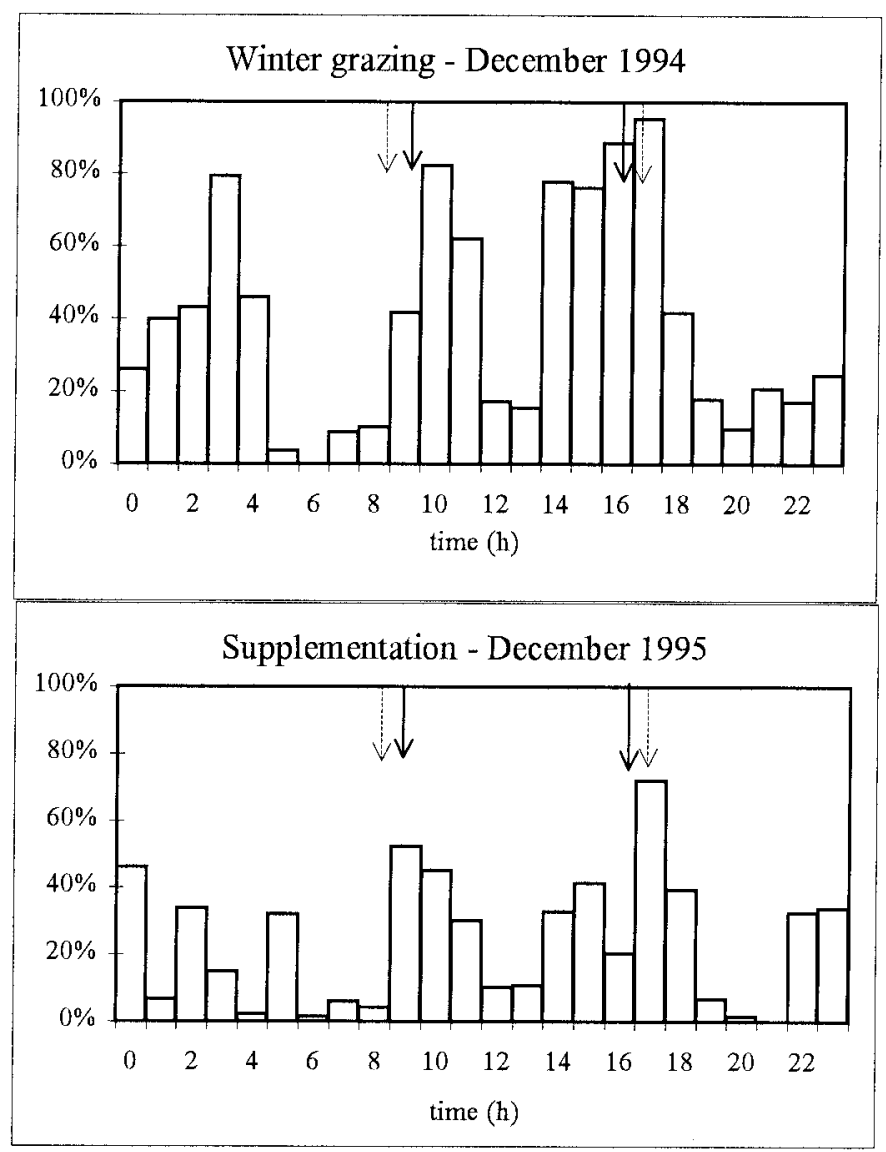

Fig. 4. Daily activity pattern of yearling bison durng winter grazing (top) and during supplementation (bottom). Sunrise-sunset indicated by solid arrows. Daylight-dark indicated by broken arrows.

hour or 2 causing bedding activities to be averaged with foraging activity. While the number of foraging and bedding cycles is adequately displayed the amplitude is more accurately reflected by the single day pattern.

The number of summer foraging bouts in the current study $\left(8.0 \pm 1.0\right.$ bouts day $\left.{ }^{-1}\right)$ are intermediate to bison on northern mixed prairie $\left(10.5 \pm 0.7\right.$ feeding bouts day ${ }^{-1}$; Plumb and Dodd 1993) and bison in boreal mixed-wood forest (4-5 feeding bouts day ${ }^{1}$; Hudson and Frank 1987). Winter grazing activity patterns in the current study were similar to autumn activity patterns observed by Hudson and Frank (1987).

Seasonal changes in foraging activity for bison appear related to more than just biomass as sward biomass varied little throughout the year, but foraging bout length and total foraging time increased from summer to winter. The role of snow cover and photoperiod as it affects annual requirements remain to be determined for bison (Rutley 1998).

As expected, foraging time increased foraging behavior. Foraging and resting cycles of bison (this study) and reindeer to winter. Unexpectedly, time in minor activities remained constant. Current data do not support the hypotheses that foraging bouts would be longer and less frequent in winter versus summer.

Provision of supplemental feed alter analysis.
(Eriksson et al. 1981) became less distinct. Bison allocated less time to grazing while supplemented which is consistent with cattle (Krysl and Hess 1993). For bison, time allocated to minor activities was similar to time allocated during summer grazing, even though daytime temperatures ranged between -12 and $-22^{\circ} \mathrm{C}$ during supplementation. DelGiudice et al. (1994) found supplemented bison to exhibit more favorable urea nitrogen to creatinine (U:C) and potassium to creatinine $(\mathrm{K}: \mathrm{C})$ ratios than free-grazing Yellowstone bison indicative of less nutritional stress.

\section{Foraging Activity}

Time allocated to summer grazing (470 min day ${ }^{-1}, 45 \%$ of daylight hours) was considerably greater than that of bison on the National Bison Range in Montana (178 min day ${ }^{-1}$, daylight hours, Belovsky and Slade 1986), but less than bison grazing boreal pastures in central Alberta (8.7 hours day ${ }^{-1}$, Hudson and Frank 1987). Despite differences in latitude, ecotype and nighttime foraging activity, time foraging (expressed as a percentage of daylight; $45 \%$ in current study) is equivalent to the $44 \%$ reported by Plumb and Dodd (1993) for bison grazing northern mixed prairie in South Dakota.

\section{Winter Grazing}

In the current study, yearling bison grazed when snow depth was $39 \mathrm{~cm}$ (December 1994) but not when snow depth was $47 \mathrm{~cm}$ (December 1995). Under the deeper snow conditions, yearling bison consistently utilized the plowed roadway for "relatively easy and energy-efficient travel" as do Yellowstone bison (Meagher 1989). Reynolds and Peden (1987) reported little differences in feeding and nonfeeding sites for snow depth and density; however, in March 1995 following a chi-

Table 5. Chemical composition of forage within feeding station (emulated bites), grazed patches and sward sites for yearling bison grazing seasonal pasture.

\begin{tabular}{lcccc}
\hline \hline & $\begin{array}{c}\text { Feeding } \\
\text { station }\end{array}$ & $\begin{array}{c}\text { Grazed } \\
\text { patches }\end{array}$ & $\begin{array}{c}\text { Sward } \\
\text { sites }\end{array}$ & SEM \\
\hline Crude Protein $(\%)^{1,2}$ & 12.9 & 10.0 & 8.7 & 0.8 \\
Calcium (\%) & 0.65 & 0.67 & 0.54 & 0.05 \\
Phosphorus (\%) & 0.22 & 0.20 & 0.19 & 0.01 \\
Potassium (\%) & 1.8 & 1.5 & 1.3 & 0.1 \\
Magnesium (\%) & 0.26 & 0.27 & 0.26 & 0.02 \\
Sodium (\%) & 0.03 & 0.03 & 0.03 & 0.01 \\
Acid Detergent Fibre $(\%)^{1}$ & 31.9 & 38.8 & 39.0 & 0.9 \\
Digestible Energy (Mcal kg $\left.{ }^{-1}\right)$ & 2.70 & 2.17 & 2.21 & 0.09 \\
Acid Detergent Lignin $(\%)^{2}$ & 4.8 & 6.8 & 6.1 & 0.3 \\
\hline
\end{tabular}

${ }^{\mathrm{T}}$ Crude protein and acid detergent fibre significantly different at $\mathrm{P}<0.05$ under GLM-Multivariate analysis.

${ }^{2}$ Crude protein and acid detergent lignin significantly different at $\mathrm{P}<0.05$ under GLM-Multivariate 
Table 6. Influence of snow depth and condition on grazing behaviour of yearling bison.

\begin{tabular}{lcccc}
\hline \hline Date & Site $^{1}$ & Depth & Snow Condition $^{2}$ & Behavior $^{3}$ \\
\hline 12 \& 13 Dec. 1994 & Snow station & $39 \pm 1.3$ & Powder & Graze \\
21 Dec. 1994 & Snow station & $22 \pm 0.4$ & Powder & Graze \\
22 Dec. 1994 & Sward Site & $23 \pm 0.7$ & Powder & Graze \\
23 Dec. 1994 & Grazed Patch & $23 \pm 1.7$ & Powder & Graze \\
14 \& 15 Mar. 1995 & Snow Station & $28 \pm 3.8$ & Hard Pack & No Graze \\
20 \& 21 Mar. 1995 & Snow Station & $26 \pm 0.8$ & New over pack & No Graze \\
22 Mar. 1995 & Snow Station & $17 \pm 1.3$ & New over pack & No Graze \\
23 Mar. 1995 & Sward Site & $23 \pm 2.4$ & New over pack & No Graze \\
24 Mar. 1995 & Grazed Patch & $13 \pm 0.8$ & New over pack & Supple. Graze \\
Dec. 1995 & Snow station & $47 \pm 0.2$ & Powder & No Graze \\
\hline
\end{tabular}

${ }^{\mathrm{T}}$ Combined measurements from a snow station and within sward sites and grazed patches.

${ }^{2}$ Powder $=$ crystallized powder snow easily moved by grazing bison. Hard Park = packed snow that yearling bison were unable to penetrate. New over pack = fresh powder over existing Hard Pack.

${ }_{4}^{3} \mathrm{Graze}=$ forage intake exclusively from grazing; No Graze $=$ refused to graze - forage intake from supplemented hay.

${ }^{4}$ Bison voluntarily grazed exposed forage, therefore forage intake 24 Mar., 1995 was from both grazing and supplemented hay.

nook, bison grazed patches with a more limited snow cover $(13 \mathrm{~cm})$ than the sward $(23 \mathrm{~cm})$. Deeper snow $(43 \mathrm{~cm})$ associated with higher elevations "had a more compromising effect on the nutritional status" of Yellowstone bison than the lower snow depths $(8 \mathrm{~cm})$ of the lower ranges (DelGiudice et al. 1994).

Condition of snow pack affected grazing behavior (Reynolds and Peden 1987, Meagher 1989). Telfer and Kelsall (1984) rated bison as having little adaptive ability for feeding above the snow. McHugh (1953) observed that bison do not paw to expose snow covered forage. Consistently, yearling bison had difficulty foraging when the sward was covered with a hard snow pack (March 1995) because they rarely clipped off exposed forage and pawed infrequently.

Group size and experience contribute to bison's ability to winter graze. In December 1995, 42, two-year old bison in an adjacent field, and herds within the Peace Country, continued to graze in the presence of $47 \mathrm{~cm}$ of snow. Prior experience and acquired knowledge enable mixed bison herds in Yellowstone National Park to forage regularly in snows $60 \mathrm{~cm}$ deep (Meagher 1989).

\section{Grazing Behavior and Diet Selection}

Although bison are roughage grazers adapted to low quality forage, they are selective when conditions allow (Peden et al. 1974, Belovsky 1986, Plumb and Dodd 1993, Coppedge et al. 1998). Bison (this study) consistently consumed the upper portion of the plant. This enabled them to consume a diet that was higher in $\mathrm{CP}$ and $\mathrm{DE}$, and lower in ADF and ADL, compared to forage available to them from within grazed patches and the sward.
In cattle and sheep, rumination and eating time are shorter when neutral detergent fibre (NDF) of consumed forage is lower (Welsh and Smith 1969, 1970). In elk and mule deer, mean retention time increases as lignin content increases; mean cell wall thickness increases linearly as NDF increases; and mean cell wall thickness is related to mean particle breakdown time (Spalinger et al. 1986). Therefore, selection of a diet low in fiber and lignin would ultimately decrease rumination, handling and mean retention time, thus enabling bison to consume greater quantities of high quality forage. Although bison are known for their ability to utilize poor quality forages, it is clear that when high quality forage is available, they will actively select it. In addition, when forage within the sward is of poorer quality, as it is in winter, bison continue to be selective by continuing to graze the upper portions of the plant.

\section{Scanning Frequency and 24-hour Observation Scans}

Boertje (1985) hypothesized that one could base 24-hour activity patterns as an extrapolation of a single active-rest cycle, thus reducing the need for nighttime observations. Collins and Smith (1989) observed free-grazing reindeer (24-hour observations) on the Seward Peninsula, Alaska and observed that daytime-only observations overestimated feeding by 37\%. Plumb and Dodd (1993) discontinued nighttime observations of bison because they observed very little grazing activity during preliminary observations. Current observations with free-grazing bison would, however, support the conclusion of Collins and Smith (1989) that "behavior budgets based on daytime observations [only] may be significantly biased and of questionable value".

Frequency of activity scans was evaluated during this study. Compared to 5minute scans (benchmark), scans at 10 and 15-minute intervals provided records of foraging activity that varied from the bench mark by -55 to $35 \%$ and -10 to $30 \%$, respectively. Minor activities occurred infrequently and in one, 2-hour segment, 10-minute scan overestimated minor activity by $200 \%$ and 15 -minute scans missed the activity completely, with a concurrent $30 \%$ overestimation of grazing activity. Therefore, 5-minute activity scans are considered necessary to adequately categorize activity in small group free-grazing bison.

\section{Conclusions and Management Implications}

Bison altered their activity budget from summer to winter by increasing foraging time and decreasing bedding time. Total time foraging and bedding bout length were greatest during winter grazing. Activity budget is best described as polyphasic, alternating between bouts of foraging and resting activity. Activity was distinctly triphasic during winter grazing bouts when bison displayed 2 main daytime foraging bouts and significant nighttime foraging activity. Phasic activity was poorly expressed during June and September grazing periods primarily due to the increase in the number of foraging bouts.

Seasonal changes in foraging activity for bison appear more related to forage quality than biomass. Bison graze selectively throughout the year by consistently consuming the upper portion of the plant which was lower in acid detergent fiber and lignin, thus higher in crude protein and digestible energy than that available from within grazed patches and the sward.

Yearling bison are able to winter graze under adequate sward cover and in acceptable snow conditions. Under more severe snow conditions, yearling bison maintained separate from the main herd, require supplementation. Provision of supplemental feed, however, alters foraging behavior, therefore managers must select a winter feeding program that is consistent with their overall management goals.

\section{Literature Cited}

Altmann, J. 1974. Observational study of behavior: sampling methods. Behavior. 49:227-267. 
Belovsky, G.E. 1986. Optimal foraging and community structure: implications for a guild of generalist grassland herbivores. Oecologia (Berlin) (1986):70:35-52.

Belovsky, G.E. and J.B. Slade. 1986. Time budgets of grassland herbivores: body size similarities. Oecologia (Berlin) (1986):70:53-62.

Boertje, R.D. 1985. Seasonal activity of the Denali caribou herd, Alaska. Rangifer 5:32-42.

Collins, W.B. and T.S. Smith. 1989. Twentyfour hour behaviour patterns of free-ranging reindeer in winter. Rangifer 9:2-8.

Coppedge, B.R., D.M. Leslie, Jr., and J.H. Shaw. 1998. Botanical composition of bison diets on tallgrass prairie in Oklahoma. J. Range Manage. 51:379-382.

DelGiudice, G.D., F.J. Singer, U.S. Seal, and G. Bowser. 1994. Physiological responses of Yellowstone bison to winter nutritional deprivation. J. Wildl. Manage. 58:24-34.

Eriksson, L-O., M-L Kallqvist, and T. Mossing. 1981. Seasonal development of circadian and short-term activity in captive reindeer, Rangifer tarandus L. Oecologia (Berlin) (1981):48:64-70.

Gates, C.C. and R.J. Hudson. 1983. Foraging behaviour of wapiti in a boreal forest enclosure. Naturaliste Can. 110:197-206.

Hudson, R.J. and S. Frank. 1987. Foraging ecology of bison in aspen boreal habitats. J. Range Manage. 40:71-75.
Hudson, R.J. and W.G. Watkins. 1986. Foraging rates of wapiti on green and cured pastures. Can. J. Zool. 64:1705-1708.

Krysl, L.J. and B.W. Hess. 1993. Influence of supplementation on behaviour of grazing cattle. J. Anim. Sci. 71:2546-2555.

McHugh, T. 1953. Social behaviour of the American buffalo (Bison bison). Zoologica 43:1-40.

Meagher, M. 1989. Range expansion by bison of Yellowstone National Park. J. Mamm. 70(3):670-675

Peden, D.G., G.M. Van Dyne, R.W. Rice, and R.M. Hansen. 1974. The trophic ecology of Bison bison L. on shortgrass plains. J. Appl. Ecol. 11:489-498.

Plumb, G.E. and J.L. Dodd. 1993. Foraging ecology of bison and cattle on a mixed prairie: implications for natural area management. Ecol. Appl. 3:631-643.

Renecker, A.L. and R.J. Hudson. 1993. Morphology, bioenergetics and resource use: patterns and processes. p 141-16 In: J. B. Stelfox (ed.), Hoofed mammals of Alberta. Lone Pine Publishing, Edmonton, Alberta.

Reynolds, H.W. and D.G. Peden. 1987. Vegetation, bison diets, and snow cover. $\mathrm{p}$ 39-44. In: H. W. Reynolds and A. W. L. Hawley (eds.), Bison ecology in relation to agricultural development in the Slave River Lowlands, NWT. Occasional Paper, No. 6

Rutley, B.D. 1998. Management, growth and performance of bison (Bison bison) on seasonal pastures. PhD Thesis, Univ. of Alberta. Edmonton, Alberta.
Rutley, B.D. and R.J. Hudson. 2000. Seasonal energetic parameters of free-grazing bison (Bison bison). Can. J. Anim. Sci. 80:663-671.

Rutley, B.D., C.M. Jahn, and R.J. Hudson. 1997. Management, gain and productivity of Peace Country bison (Bison bison). Can. J. Anim. Sci. 77:347-353.

SAS Institute Inc. 1996. SAS/STAT user's guide. Version 6.21 of MS Windows, SAS Institute, Inc. Cary, NC.

Spalinger D.E., C.A. Robbins, and T.A. Hanley. 1986. The assessment of handling time in ruminants: the effect of plant chemical and physical structure on the rate of breakdown of plant particles in the rumen of mule deer and elk. Can. J. Zool. 64:312-321.

Telfer, E.S. and J.P. Kelsall. 1984. Adaptation of some large North American mammals for survival in snow. Ecol.. 65:1824-1834.

Trudel, J. and R.G. White. 1981. The effect of forage structure and availability on food intake, biting rate, bite size and daily eating times of reindeer. J. Appl. Ecol. 18:63-81.

Welsh, J.G. and A.M. Smith. 1969. Influence of forage quality on rumination time in sheep. J. Anim. Sci. 28:813-818.

Welsh, J.G. and A.M. Smith. 1970. Forage quality and rumination time in cattle. J. Dairy Sci. 53:797-800. 